\title{
An invasive mosquito species Aedes albopictus found in the Czech Republic, 2012
}

O Šebesta ${ }^{1,2}$, I Rudolf ${ }^{1}$, L Betášová ${ }^{1}$, J Peško ${ }^{1}$, Z Hubálek (zhubalek@brno.cas.cz)

1. Institute of Vertebrate Biology, v.v.i., Academy of Sciences of the Czech Republic, Brno, Czech Republic

2. Regional Public Health Authority of South Moravian Region, Brno, Czech Republic

Šebesta 0, Rudolf I, Betášová L, Peško J, Hubálek Z. An invasive mosquito species Aedes albopictus found in the Czech Republic, 2012. Euro Surveill. 2012;17(43):pii=20301. Available online: http://www.eurosurveillance.org/ViewArticle.aspx?Articleld=20301

Article submitted on 02 October 2012 / published on 25 October 2012

Between July and September 2012, seventeen larvae of the invasive mosquito species Aedes (Stegomyia) albopictus (Skuse) were discovered using 60 ovitraps at four study sites alongside two main road exits in South Moravia, Czech Republic. This is the first report of imported Ae. albopictus in the Czech Republic. The findings highlight the need for a regular surveillance programme to monitor this invasive species throughout western and central Europe.

\section{Background}

Of the invasive mosquitoes discovered in Europe recently, the Asian tiger mosquito Aedes albopictus (Skuse) represents the major threat to public health. Historically, this species originated in SouthEast Asia, but it has spread to the Americas, parts of Africa, northern Australia, and 19 European countries (Albania, Belgium, Bosnia and Herzegovina, Bulgaria, Croatia, France, Germany, Greece, Italy, Malta, Monaco, Montenegro, the Netherlands, San Marino, Serbia, Slovenia, Spain, Switzerland, Vatican City State) during the last decades. The species is now widely established and reportedly a nuisance mosquito in Italy, parts of France and Spain [1]. Ae. albopictus is globally an important vector of human pathogens such as chikungunya and dengue viruses as well as filarial nematodes represented by Dirofilaria spp., and an experimentally proven vector of eastern equine encephalitis, Venezuelan equine encephalitis, La Crosse encephalitis, Japanese encephalitis, West Nile and several other viruses [2,3].

Its eggs are frequently transported via used tire trade or by importation of lucky bamboo [2]. However, the most important mode of long-distance dispersal of Ae. albopictus in Europe in the last decade seems to be transportation by ground vehicles (i.e. lorries, cars, caravans) from southern Europe [4,5].

While two frequently used main roads connecting the Czech Republic with southern European countries cross the border in South Moravia, no systematic surveillance of invasive mosquito species has been conducted until present. This led us to periodically monitor invasive mosquito species at this so-called 'Moravian entrance gate' using ovitrap installations.

\section{Trapping of mosquitoes}

To monitor the presence of Ae. albopictus we used traditional ovitraps [6]. These were constructed from a dark blue $800 \mathrm{ml}$ plastic cup and supplemented with $500 \mathrm{ml}$ of dechlorinated tap water and a floating wooden tongue depressor paddle wrapped into rough cotton fabric that was in contact with the water line to ensure Ae. albopictus oviposition. Ovitraps were placed on shrubs, columns or public lighting in close proximity to parking spaces about $50 \mathrm{~cm}$ above the ground. Wooden paddles and water were periodically replaced (every 7 days) and transported in closed containers to the laboratory. The paddles were incubated at $25^{\circ} \mathrm{C}$ in humid atmosphere for three days and then kept immersed below the water surface at $25^{\circ} \mathrm{C}$ for another 12 days. Additionally, water from the ovitrap containers was incubated in the laboratory at $25^{\circ} \mathrm{C}$ for one week. Both components were daily examined for the presence of hatching eggs or larvae. Larvae and adults reared from larvae were morphologically identified according to recent entomological keys $[6,7]$.

\section{Study sites and findings}

Several ovitraps were placed at four study sites (parking lots) in close proximity to exits of two main roads respectively connecting Austria and Slovakia with the Czech Republic (Figure). A total of 60 ovitraps were installed between the beginning of July and the end of September 2012.

The first two ovitrap sites (study sites 1 and 2) were situated near the main road $\mathrm{E} 65$, a transit route for goods to the Czech Republic from Slovakia and Hungary as well as from Balkan countries (Romania, Bulgaria, Croatia, Serbia, Greece). Individual and collective transport between western (e.g. Germany, Belgium, the Netherlands), central and southern Europe also operates through this main road. Study site 1 (22 ovitraps) was in Lanžhot (N 48 ${ }^{\circ} 43,554^{\prime}$, E016 ${ }^{\circ} 59,041^{\prime}, 155$ $\mathrm{m}$ above sea level (a.s.l.)), at a one km distance from Slovakia. The location is used for refreshment and 


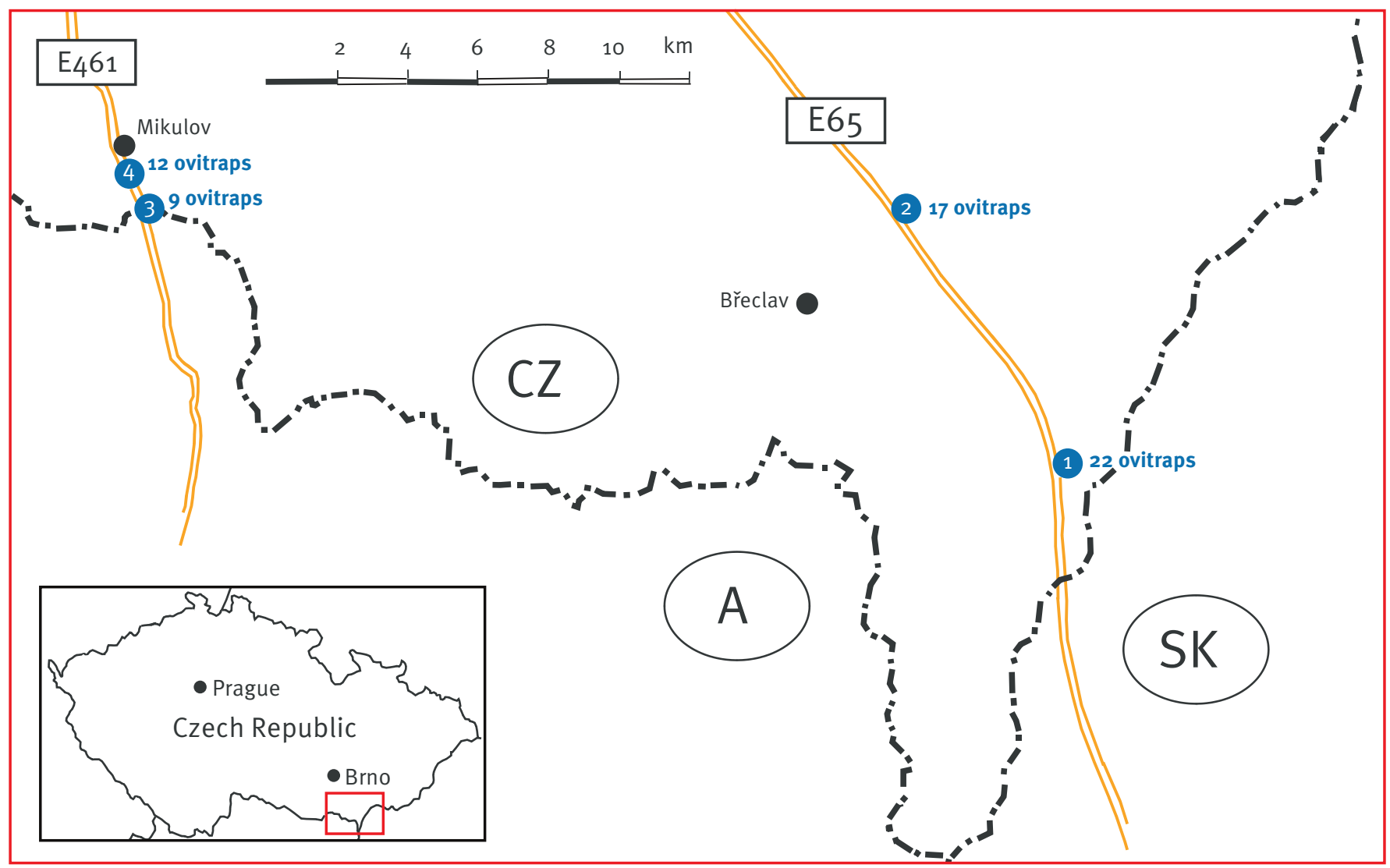

Location where ovitraps were placed, the number in the circle indicates the site number for the purpose of the study.

A: Austria; CZ: Czech Republic; SK: Slovakia.

Mosquito traps (ovitraps) were placed at four locations near the two main roads E461 and E65 which are respectively shown on the map in yellow.

refueling, with a parking capacity of about 100 spaces. Study site 2 (17 ovitraps) was at Ladná (N 4848,669', E016 ${ }^{\circ} 53,600^{\circ}, 177 \mathrm{~m}$ a.s.l.) and situated approximately $16 \mathrm{~km}$ north of the first study site alongside the same main road. The site serves mainly as a refueling and rest area with a parking capacity of about 40 spaces. Two additional ovitrap sites (study sites 3 and 4) were chosen beside main road E461, where this road enters the Czech Republic from Austria. The main road E461 is frequently used for transit of goods from southern Europe (Italy, Slovenia, Croatia, Serbia, Montenegro, Macedonia, Albania) to the (zech Republic. Study site 3 (9 ovitraps) was Mikulov II (N 48 ${ }^{\circ} 47,424^{\prime}$, E016 $6^{\circ} 38,154^{\prime}$, 198 m a.s.l.), a former customs' house now solely intended for refreshment. It is located on the CzechAustrian border and has a parking capacity of about 10 spaces. Study site 4 (12 ovitraps) was Mikulov I (N $48^{\circ} 47,845^{\prime}, \mathrm{E}_{016^{\circ}} 37,970^{\prime}, 207 \mathrm{~m}$ a.s.l.), at the periphery of the town of Mikulov about $1.2 \mathrm{~km}$ north of study site 3 . It serves a rest and refueling purpose and has a parking capacity of about 20 spaces.
From study site 4, we found 16 larvae of Ae. albopictus. Eight larvae in stage IV were euthanised for identification while the remaining eight were left to rear to adult stage (five females and three males) and also subsequently identified. Interestingly, all mosquito larvae developed from ovitraps set up within two subsequent intervals (20 August and 27 August 2012). Furthermore, one larva of Ae. albopictus developed from an ovitrap situated at the study site 3, on 10 September 2012, while no deposited eggs were detected in the study sites 1 and 2.

\section{Conclusion}

South Moravia is owing to its mild climate the most favourable habitat for breeding of mosquitoes within the Czech Republic [8]. Massive broods of mosquitoes (predominantly Aedes spp.) periodically occur here along the rivers Dyje and Morava. This area has been known for a long time as a natural focus of several mosquito-borne viruses: mainly Ťahyňa virus, the etiologic agent of Valtice fever, and since 1997 also 
West Nile virus lineage 3 - Rabensburg $[9,10]$. Many mosquito species occurring in the Czech Republic were only recorded in this region, e.g. Anopheles atroparvus, An. hyrcanus, An. labranchiae, Aedes nigrinus, Uranotaenia unguiculata, Culex martinii [11,12]. We should take this region into consideration when searching for a suitable habitat for possible introduction and subsequent establishment of invasive mosquito species in central Europe. Our findings suggest that Ae. albopictus may be able to complete its developmental cycle in this region, and in case of a mild winter might also survive in the stadium of eggs [13]. Our results also indicate that ovitraps are a suitable tool for monitoring invasive mosquitoes on parking lots alongside main roads where alternative egg depositing water is likely less available.

In conclusion, we provide the first evidence of import of Ae. albopictus in the Czech Republic. Interestingly, Ae. albopictus has not yet been reported from the neighbouring central-European countries Austria, Slovakia, Hungary or Poland.

\section{Acknowledgments}

We are grateful to František Rettich and Francis Schaffner for confirmation of the mosquito species identity. This study was partially funded by the EU grant FP7-261504 EDENext, and it is catalogued as EDENexto72. The input for the study was given by VBORNET (European network of medical entomologists and public health experts) under ECDC service contract ECD 2009/018. The work was also supported by the Institutional Research Plan of the Institute of Vertebrate Biology AS CR, v.v.i. (RVO:68081766).
References

1. Medlock JM, Hansford KM, Schaffner F, Versteirt V, Hendrickx $\mathrm{G}$, Zeller $\mathrm{H}$, et al. A review of the invasive mosquitoes in Europe: ecology, public health risks, and control options. Vector Borne Zoonotic Dis. 2012;12(6):435-47.

2. Gratz N. Critical review of the vector status of Aedes albopictus. Med Vet Entomol. 2004;18(3):215-27.

3. Scholte EJ, Schaffner F. Waiting for the tiger: establishment and spread of the Aedes albopictus mosquito in Europe. In Takken W, Knols BGJ, editors. Emerging pests and vectorborne diseases in Europe. Wageningen: Wageningen Academic Publishers; 2007.

4. Pluskota B, Storch V, Braunbeck T, Beck M, Becker N. First record of Stegomyia albopicta (Skuse) (Diptera: Culicidae) in Germany. Eur Mosq Bull. 2008;26:1-5.

5. Werner D, Kronefeld M, Schaffner F, Kampen H. Two invasive mosquito species, Aedes albopictus and Aedes japonicus, trapped in south-west Germany, July to August 2011. Euro Surveill. 2012;17(4):pii=20067. Available from: http://www. eurosurveillance.org/ViewArticle.aspx?Articleld=20067

6. Becker N, Petrič D, Zgomba M, Boase C, Madon M, Dahl Ch, et al. Mosquitoes and their control. 2nd ed. Heidelberg: Springer; 2010.

7. Schaffner F. Mosquitoes in used tyres in Europe: species list and larval key. Eur Mosq Bull. 2003;16:7-12.

8. Šebesta O, Gelbič I, Minář J. Mosquitoes (Diptera: Culicidae) of the Lower Dyje River Basin (Podyjí) at the Czech-Austrian border. Cent Eur J Biol. 2012;7(2):288-98.

9. Hubálek Z, Savage HM, Halouzka J, Juřicová Z, Sanogo YO, Lusk $\mathrm{S}$. West Nile virus investigations in South Moravia, Czechland. Viral Immunol. 2000;13(4):427-33.

10. Hubálek Z, Rudolf I, Bakonyi T, Kazdová K, Halouzka J, Šebesta O, et al. Mosquito (Diptera: Culicidae) surveillance for arboviruses in an area endemic for West Nile (Lineage Rabensburg) and Tahyna viruses in Central Europe. J Med Entomol. 2010;47(3):466-72.

11. Šebesta O, Rettich F, Minář J, Halouzka J, Hubálek Z, Juřicová Z, et al. Presence of the mosquito Anopheles hyrcanus in South Moravia, Czech Republic. Med Vet Entomol. 2009;23(3):284-6.

12. Šebesta O, Halouzka J, Hubálek Z, Juřicová Z, Rudolf I, Šikutová $S$, et al. Mosquito (Diptera: Culicidae) fauna in an area endemic for West Nile virus. J Vector Ecol. 2010;35(1):156-62.

13. Thomas SM, Obermayr U, Fischer D, Kreyling J, Beierkuhnlein C. Low-temperature threshold for egg survival of a postdiapause and non-diapause European aedine strain, Aedes albopictus (Diptera: Culicidae). Parasit Vectors. 2012;5:100. 